УДК 159.9. 379.8

DOI https://doi.org/10.32838/2709-3093/2021.3/06

Масюк А.Ю.

Київський національний університет імені Тараса Шевченка

Мілютіна К.Л.

Київський національний університет імені Тараса Шевченка

\title{
ТОЛЕРАНТНІСТЬ ДО НЕВИЗНАЧЕНОСТІ ТА ОСОБЛИВОСТІ ОСОБИСТОСТІ ЯК ЧИННИКИ ЧИТАЦЬКИХ УПОДОБАНЬ МОЛОДІ
}

Роботу присвячено проблемі особистісних чинників читацьких вподобань осіб юнацького віку. Нами була використана процедура емпіричного дослідження, яка включала в себе застосування психодіагностичної методики «П'ятифакторний опитувальник особистості $5 P F Q »$, опитувальник толерантності до невизначеності Баднера та анкетування, а також метод корелячійного аналізу Пірсона для математично-статистичної обробки. Було проведено тестування 140 осіб у віці 18-25 років. Для визначення читацьких вподобань було створено авторську анкету, яка включає в себе запитання про улюблені та неулюблені жанри книг. Було використано класифікацію П. Рентфроу [1]. Фактори включають в себе: Популярність (любовні романи, релігія, кулінарія тощо), Естетика (поезія, книги про мистецтво), Темнота (жахи, еротика, драма), Пригоди (пригоди, шпіонські детективи, фантастика), Факти (наукова література, біографії, бізнес, новини). Наявний прямий зв'язок прив'язаності з факторами Популярність та Естетика та обернений зв'язок з фактором Темрява. Люди з високими проявами Самоконтролю часто обирають літературу з фактору Факти, тобто бізнес літературу, біографії тощо. Також такі люди менше за все читають жанри з фактору Пригоди. Високий нейротизм сприяє інтересу до різних жанрів, об'єднаних фактором Темрява. Низький показник нейротизму, тобто емоиійна стабільність, вказує на інтерес респондентів до жанрів з факторів Факти і Пригода. Експресивність негативно корелює з факторами Популярність і Пригоди, а позитивно - з фактором Темрява. Толерантність до невизначеності позитивно корелює з факторами Темрява і Пригоди і негативно - з Фактами і Популярністю. Перспективою подальших досліджень стане виявлення вікової динаміки читацьких уподобань та наявність співпадіння (розбіжностей) між читаџькими та глядацькими вподобаннями.

Ключові слова: особистість, читання, жанри, толерантність до невизначеності, молодь.

Постановка проблеми. В сучасних реаліях читацька активність молоді має тенденцію до зниження, ця проблема викликає тривогу у великого кола фахівців: культурологів, соціологів, педагогів, бібліотекознавців, книговидавців. Психологічні дослідження читацьких уподобань дозволяють глибше зрозуміти особливості індивідуального стилю пізнавальної діяльності. Ми висунули припущення, що риси особистості та толерантність до невизначеності можуть зумовлювати читацькі вподобання молоді.

Аналіз останніх досліджень та публікацій. Увагу сучасних дослідників привертає сам факт читання - переважає стратегія читання паперових видань або з екрану. У дослідженні брало 82 учнів п'ятого та шостого класів, які читають тексти на екрані комп'ютера та на папері. Вони відповідали на запитання про розуміння та оцінювали свою впевненість у своїх відповідях. Крім того, вони заповнювали анкети переваг до і після виконання завдання. Результати показали, що діти воліють читати з екрану. В той же час вони працювали значно краще під час читання паперової книги і були більш впевненими у своїх відповідях щодо розуміння тексту, ніж під час читання з екрану. Наприклад, у дослідженні соціолога М.М. Самохіної «Читання молоді: XXI століття» показується той факт, що в загальному знизилась «якість читання», тобто під час пошуку інформації пріоритетними стали електронні форми тексту, читання як форма дозвілля має тенденцію до зниження, превалює в основному розважальна і прагматична мотивація у формуванні кола читання, жанрово-тематичні уподобання досить обмежені. [3]. Говорячи про жанрові уподобання молоді, можна звернутися до дослідження Т.Б. Ловкової, яка зазначає, що молоді люди здебільшого надають перевагу таким літературним жанрам, як фентезі, детектив, 
мелодрама, пригоди, трилер і містика [4]. Названі вище літературні жанри по суті своїй є розважальними, що говорить нам про те, що читання молоді має розважальний характер. Резюмуючи вищеописане, можна зробити висновок про те, що загалом змінюється якість читання сучасної молоді, тому досить актуальними є дослідження основних факторів, що впливають на особливості читацьких інтересів молоді. Ці фактори досить різноманітні і зачіпають різні сфери діяльності молодих людей. Аналізуючи вибір читачів тієї чи іншої літератури, дослідники виділяють термін «зацікавленість текстом», що вказує на психологічний стан, який поєднує концентрацію уваги 3 позитивним емоційним тоном читання і характеризується оптимальним рівнем процесів сприйняття, мислення, уяви, запам'ятовування. У цьому стані читачеві не доводиться постійно напружувати волю, щоб зосередитися. Навпаки, його важко буває відвернути, настільки велике бажання продовжувати читання. Розрізняють ситуативну й особистісну зацікавленість людини в читанні.

Ситуативна зацікавленість визначається насамперед зовнішніми характеристиками видання. Яскраві ілюстрації привертають увагу не тільки дітей, а й більшості дорослих читачів. Іноді привертає увагу обкладинка книги, назва, цікавість, новизна думки або іiі подача автором. Зрештою ситуативна зацікавленість - це наслідок відповідності ситуації особливостям читацької психіки.

Особистісна зацікавленість - це прояв стійких властивостей особистості (потреб, інтересів, здібностей тощо) Людина, яка має сильний інтерес до будь-якої сфери, зазвичай сама шукає ситуації, які дозволили б їй віддатися своєму інтересу. Домінуючі духовні інтереси особистості зазвичай породжують зацікавленість під час читання відповідної літератури [5].

А.А. Сергієнко вважає, що аби зацікавити учнів творами сучасних письменників, книгами для додаткового читання, учитель не може обійтися без літературних практикумів, на які школярі будуть готувати рекламні ролики та літературні білборди, буктрейлери та презентації, колажі та летбуки, пазли і ментальні карти, картини та ілюстрації, створювати віртуальні сторінки письменників у соціальних мережах, писати відгуки тощо [6]. Деякі автори виділяють істинні та помилкові читацькі уподобання. Перебільшуючи емоційну привабливість певної літератури, помилковий інтерес завищує ступінь її відповідності реальним потребам в читанні і спотворює їх. Дуже важливо відділити істинні інтереси від помилкових під час соціально-психологічного аналізу масового читання. Масова маніпуляція інтересами читацької аудиторії слугує засобом дезорієнтації і відволікання від соціально значимих інтересів. Для цього слід розвивати читацький смак, тобто здатність суб'єкта до самостійного судження про переваги творів літератури [7; 8]. Kuijpers M., Douglas S., \& Kuiken D. [9] підкреслюють, що досвід поглинання наративів широко вивчався в останні роки, відносно мало відомо про риси особистості читачів, які регулярно захоплюються читанням фантастики. У цьому дослідженні вивчалося, які риси особистості передбачають поглинання читанням. В ході опитування в Інтернеті студенти - початківці психології $(\mathrm{N}=264)$ описали свій найпам'ятніший досвід читання за останній рік та детально описали цей досвід, заповнивши шкалу поглинутості історією або світом. Результати показують, що показники особистості відображають різні аспекти «глобальної відкритості досвіду», вплив рис особистості на читання зазвичай опосередковується читацькими звичками, стійкою концентрацією та гнучкістю уваги.

N. Annalyn, M.W. Bos, L. Sigal and B. Li, [10] використали сучасні методи аналізу читацьких уподобань. За допомогою «тегів», створених користувачами веб-сайту для огляду книг Goodreads.com. У поєднанні 3 даними про уподобання та оцінки особистості, зібраними від користувачів Facebook, ярлики тегів забезпечують високу точність прогнозування особистості за психологічними стандартами. Крім того, автори згрупували теги в більш широкі жанри, щоб перевірити їх дійсність у порівнянні з минулими висновками. Наші результати надійні як на рівні тегів, так і на рівні жанру та відповідають наявній літературі. Навіть більше, створені користувачами ярлики тегів виявляють несподівані уявлення, такі як культурні відмінності, поведінка під час читання книг та інші неконтентні фактори, що впливають на уподобання. Наскільки нам відомо, натепер це найбільше дослідження, яке досліджує взаємозв'язок між особливостями особистості та змісту книги.

А.А. Чістова в своєму дослідженні розглянула проблему структури цінностей і читацьких уподобань [5]. Було визначено, що улюблений жанр літератури молоді - фантастика, професійна i психологічна література. При цьому молодь, яка читає 5-10 книг за три місяці, ставить в топ-5 важливих цінностей-цілей «суспільну спрямованість» у вигляді роботи, визнання і щастя інших, 
а також сміливість у відстоюванні своєї думки як у способі дії, що в сумі може говорити про те, що наявний зв'язок між читанням і ціннісною структурою, а саме цілеспрямованістю і соціальною спрямованістю, що може бути запорукою позитивного здорового розвитку особистості як соціального індивіда. Л.І. Прокопенко [11] звертає увагу на інтерес молоді до літератури психологічного, психоаналітичного, мотиваційного змісту, що сприяє внутрішньому становленню, впевненості в собі, самоствердженню та є запорукою подальшого формування духовних цінностей особистості. Попри інформаційні потоки, які формують вплив на масову аудиторію, іiі інформаційну залежність, книга залишається провідною константою культури та $€$ духовним і матеріальним складником життя.

Постановка завдання. Мета дослідження - визначити характер зв'язку між індивідуально-особистісними характеристиками сучасної молоді та їх читацькими уподобаннями.

Виклад основного матеріалу. Нами була використана процедура емпіричного дослідження, яка включала в себе застосування психодіагностичної методики «П'ятифакторний опитувальник особистості 5PFQ» та анкетування, а також метод кореляційного аналізу Пірсона для математичностатистичної обробки. «П'ятифакторний опитувальник особистості 5PFQ» було використано для визначення індивідуально-особистісних характеристик. Цей опитувальник $є$ одним 3 варіантів реалізації психологічної моделі Велика п’ятірка створена японським дослідником Хійджіро Тсуйі (Неijiro Tsuji) на основі розробок П. Коста i P. МакРае (опитувальник NEO PI-R). Вітчизняна адаптація методики виконана А.Б. Хромовим в Курганському Державному Університеті в 2000 році. Довгий час був єдиним вільно доступним опитувальником моделі Великої п'ятірки російською мовою. За допомогою цього тесту можна виміряти ступінь вираженості кожного 3 п’яти факторів «великої п’ятірки»: екстраверсія / інтроверсія, прихильність / відособленість, самоконтроль / імпульсивність, емоційна нестійкість / стійкість, експресивність / практичність. Опитувальник «Толерантність до невизначеності» С. Баднера дозволяє дослідити такі шкали, як «новизна», «складність», «нерозв’язність».

Для визначення читацьких вподобань було створено авторську анкету, яка включає в себе запитання про улюблені та неулюблені жанри книг. Також для ефективної інтерпретації результатів дослідження було використано класифікацію П. Рентфроу. Він разом з співавторами [1] виділили 108 мас-медійних жанрів, що належать до чотирьох сфер: музика, книги, кіно, телебачення. Респонденти оцінювали, наскільки їм подобаються зазначені жанри. Потім був проведений факторний аналіз отриманих оцінок привабливості, який дозволив виділити п'ять глобальних параметрів (факторів), що описують простір мас-медійних переваг. Щодо читацьких вподобань, то ці фактори включають в себе: Популярність (любовні романи, релігія, кулінарія тощо),

Таблиця 1

Зв'язок комунікативних особливостей особистості та читацьких уподобань

\begin{tabular}{|c|c|c|c|c|c|}
\hline & Популярність & Естетика & Темнота & Пригоди & Факти \\
\hline Екстраверсія-інтроверсія & $0,415^{*}$ & $-0,485^{*}$ & $-0,312$ & $0,487^{*}$ & 0,039 \\
\hline Активність-пасивність & $-0,286$ & $-0,389^{*}$ & 0,006 & 0,026 & 0,315 \\
\hline Дружелюбність-замкнутість & $0,483^{*}$ & 0,140 & $-0,107$ & $0,387^{*}$ & $-0,128$ \\
\hline $\begin{array}{c}\text { Пошук вражень-уникнення } \\
\text { вражень }\end{array}$ & 0,288 & $-0,419^{*}$ & 0,278 & 0,211 & 0,189 \\
\hline Прив'язаність-відокремленість & $0,509^{*}$ & $0,423^{*}$ & $-0,500^{*}$ & 0,273 & $-0,328$ \\
\hline Довірливість-підозрілість & $0,405^{*}$ & 0,066 & $-0,451^{*}$ & 0,289 & $-0,196$ \\
\hline Розуміння-нерозуміння & 0,292 & 0,120 & 0,043 & $-0,124$ & 0,325 \\
\hline Повага до інших-самоповага & 0,223 & $0,389^{*}$ & $-0,136$ & 0,040 & 0,025 \\
\hline
\end{tabular}

Примітка:* $\mathrm{p} \leq 0,01 \mathrm{p} \leq 0,05$ значимість кореляції - зв'язок між змінними 
Таблиця 2

Зв'язок емоційної сфери особистості та читацьких уподобань

\begin{tabular}{|c|c|c|c|c|c|}
\hline & Популяність & Естетика & Темнота & Пригоди & Факти \\
\hline Самоконтроль-імпульсивність & 0,289 & 0,165 & $-0,121$ & $-0,277^{*}$ & $0,396^{*}$ \\
\hline $\begin{array}{c}\text { Наполегливість-відсутність } \\
\text { наполегливості }\end{array}$ & $-0,123$ & 0,207 & 0,227 & $-0,386^{*}$ & $0,419^{*}$ \\
\hline $\begin{array}{c}\text { Відповідальність-безвідпові- } \\
\text { дальність }\end{array}$ & 0,192 & 0,296 & $-0,011$ & 0,091 & $0,421^{*}$ \\
\hline $\begin{array}{c}\text { Емоційна нестійкість-стійкість } \\
\text { Напруженість-розслабленість }\end{array}$ & $-0,287$ & 0,340 & $0,437 *$ & $-0,480^{*}$ & $-0,389 *$ \\
\hline Депресивність- емоційна & -0, & $-0,175$ & $-0,209$ & $-0,391 *$ & 0,244 \\
\hline конфомність & $-0,219$ & $-0,126$ & $0,416^{*}$ & 0,043 & $-0,209$ \\
\hline Самокритика-самодостатність & $-0,210$ & $-0,266$ & 0,076 &,- 309 & $-0,401^{*}$ \\
\hline $\begin{array}{c}\text { Експресивність-практичність } \\
\text { Допитливість-реалістичність }\end{array}$ & $-0,382^{*}$ & $-0,045$ & $0,350^{*}$ & $-0,420^{*}$ & 0,290 \\
\hline Сенситивність-нечутливість & 0,209 & 0,123 & $-0,276$ & $-0,134$ & $-0,034$ \\
\hline
\end{tabular}

Примітка:* $\mathrm{p} \leq 0,05, * * \mathrm{p} \leq 0,05$ значимість кореляції - зв'язок між змінними

Естетика (поезія, книги про мистецтво), Темнота (жахи, еротика, драма), Пригоди (пригоди, шпіонські детективи, фантастика), факти (наукова література, біографії, бізнес, новини).

Респондентами (читацькою аудиторією) стали молоді люди - юнаки та дівчата віком 18-25 років, студенти вузів, працююча молодь. Було опитано 140 респондентів. У дослідженні зв'язку індивідуальних характеристик особистості та читацьких уподобань було проведено кореляційний аналіз статистично значимих зв'язків отриманих даних. Для цього використовувався кореляційний метод Пірсона математично-статистичної обробки даних. Кореляційний аналіз Пірсона застосовується для виявлення істотного зв'язку однісї змінної дослідження з іншою, що аналізується дослідником.

Було визначено, що екстравертовані люди зазвичай обирають Популярні жанри та Пригоди i не надають перевагу жанрам Естетики (поезія, класика). Це можна пояснити тим, що ці люди енергійні, дружелюбні, оптимістичні, люблять розваги, колективні заходи, тому для них більш близька література життєва, про яку можна поговорити 3 іншими, або з цікавим, захоплюючим сюжетом та динамікою. Жанри фактору Естетика для них можуть здатися нудними. Це підтверджує i той факт, що наявний обернений зв'язок між рисою «активність» та фактором Естетика. Отже, цьому фактору надають перевагу менш активні особистості. Більш дружелюбні люди також обирають жанри з фактору Пригоди.

Прив'язаність характеризує осіб, які відчувають потребу бути поруч 3 іншими людьми. Зазвичай це добрі, чуйні люди, вони добре розуміють інших людей, відчувають особисту відповідальність за їх добробут, терпимо ставляться до недоліків інших людей. Наявний прямий зв'язок 
прив'язаності з факторами Популярність та Естетика та обернений зв'язок з фактором Темрява. Отже, такі люди з властивим їм гуманізмом і соціальною спрямованістю цікавляться відповідними жанрами з факторів і відкидають жанри фактору Темрява, в яких зображуються або схвалюються асоціальні прояви. Вплив особливостей емоційної сфери особистості відображено у таблиці 2.

Самоконтроль передбачає любов до порядку і комфорту, такі люди наполегливі в діяльності і зазвичай досягають у ній високих результатів. Результати дослідження вказують на те, що такі люди часто обирають літературу з фактору Факти, тобто бізнес-літературу, біографії тощо. Наявні позитивні кореляції цього фактору з відповідальністю та наполегливістю. Також такі люди менше за все читають жанри з фактору Пригоди. Звідси можна зробити висновок, що контроль присутній навіть у читанні, адже респонденти обирають більш дисципліновану літературу, що сприяє розвитку, а не просто для розваги та відпочинку. Високий нейротизм сприяє інтересу до різних жанрів, об'єднаних фактором Темрява. Високі значення за цим фактором характеризують осіб, нездатних контролювати свої емоції і імпульсивні потяги. Низький показник нейротизму, тобто емоційна стабільність, вказує на інтерес респондентів до жанрів 3 факторів Факти і Пригода. Експресивність, тобто риса, яка характеризує легке відношення до життя, без планування, з більшою опорою на інтуїцію, з відношенням до життя, як до гри, негативно корелює з факторами Популяр- ність і Пригоди, а позитивно - 3 фактором Темрява. Це підтверджує також наявний позитивний зв'язок між допитливістю та фактором Темрява i негативний зв'язок з факторами Популярність та Пригоди.

Толерантність до невизначеності позитивно корелює 3 факторами Темрява $(0,445)$ і Пригоди $(0,541)$ і негативно - 3 Фактами $(-0,391)$ і Популярністю $(-0,402)$.

Висновки. Проведене дослідження дозволяє створити «психологічні портрети» читачів різних типів творів. Читачі «Популярної» літератури екстравертовані, дружні, прив'язані та довірливі, не дуже полюблять невизначеність та новизну. Молодь, якій подобається «Естетика», - інтровертована, пасивна, уникає яскравих вражень та поважає інших. Читачі «Темряви» - підозрілі, дещо депресивні, але допитливі і позитивно ставляться до невизначеності та нерозв'язності. Прихильники пригодницьких текстів екстравертовані, дружелюбні, імпульсивні, емоційно стійкі та розслаблені, позитивно сприймають невизначеність у власному житті. Читачі документальних текстів наполегливі, 3 високим самоконтролем та відповідальністю, самодостатні та емоційно стійкі. Отримані результати сприяють більш раціональному пошуку видань для того, щоб зацікавити молодь читанням.

Перспективу подальших досліджень становить вивчення вікових особливостей читацьких уподобань та дослідження впливу літературних творів на переконання та рівень толерантності читачів.

\section{Список літератури:}

1. Rentfrow P.J., Goldberg L.R., Zilca R. Listening watching, and reading: The structure and correlates of entertainment preferences. Journal of Personality. 2011. V. 79. P. 223-257.

2. Danielle Dahan Golan, Mirit Barzillai, Tami Katzir, The effect of presentation mode on children's reading preferences, performance, and self-evaluations, Computers \& Education, Volume 126, 2018, P. 346-358,

3. Самохина М.М. Чтение молодежи: XXI век (по результатам исследований 2001-2011 гг.). Инновачионные формы поддержки и продвижения чтения в общедоступных библиотеках. Челябинск, 2010. $99 \mathrm{c}$.

4. Ловкова Т. Б. Досуговое чтение молодёжи в ста зеркалах. Социолог и психолог в библиотеке. 2012. № 7. С. 127-128.

5. Китаева А.И. Связь читательских диспозиций и ценностных ориентаций личности. Вестник Санкт-Петербургского университета Сер. 12. 2008. Вып. 2 С. 34-39

6. Чистова А.А. Соотношение структуры ценностей и читательских предпочтений молодежи. Вестник МГЛУ. Выпуск 16 (702). 2014. С. 112-120

7. Сергієнко А.А. Формування в учнів читацької компетентності на особистісно зорієнтованих уроках української літератури. Науковий часопис НПУ імені М. П. Драгоманова. Випуск 67’2019 Серія 5. Педагогічні науки: реалії та перспективи. С. 247-250

8. Андреева А.Д. Психологические аспекты интереса детей и подростков к литературному произведению. Психология и литература в диалоге о человеке: Материалы Международной научной конференции. 2015. C. $74-77$.

9. Тихомирова И. И. О модели чтения, ведущей к жизни. Школьная библиотека. 2017. № 4. С. 15-22. 
10. Kuijpers, M., Douglas, S., \& Kuiken, D. (2019). Personality traits and reading habits that predict absorbed narrative fiction reading. Psychology of Aesthetics, Creativity, and the Arts, 13(1), 74-88. https://doi.org/10.1037/ aca0000168.

11. Annalyn N., M. W. Bos, L. Sigal and B. Li, "Predicting Personality from Book Preferences with User-Generated Content Labels" in IEEE Transactions on Affective Computing, vol. 11, no. 3, pp. 482-492, 1 July-Sept. 2020, doi: 10.1109/TAFFC.2018.2808349.

12. Прокопенко Л.І. Читання як складова у формуванні культури сучасної молоді. Культура $i$ мистеитво у сучасному світі.2019. DOI:10.31866/2410-1915.20.2019.172431.

\section{Masyuk A.Yu., Milyutina K.L. TOLERANCE TO UNCERTAINTY AND PERSONALITY FEATURES AS FACTORS OF YOUNG PEOPLE'S READING LIKES}

The work is devoted to the problem of personal factors of reading preferences of young people. We used an empirical study procedure that included the use of the 5PFQ Five-Factor Personality Questionnaire, the Badner Uncertainty Tolerance Questionnaire, and the Pearson Correlation Analysis Method for Mathematical and Statistical Processing. 140 people aged 18-25 were tested. To determine readers' preferences, an author 's questionnaire was created, which includes questions about favorite and unloved genres of books. P. Rentfrow's classification was used. Factors include: Popularity (love novels, religion, cooking, etc.), Aesthetics (poetry, art books), Darkness (horror, erotica, drama), Adventure (adventure, spy detectives, fiction), Facts scientific l-tour, biographies, business, news). There is a direct relationship of attachment to the factors of Popularity and Aesthetics and an inverse relationship with the factor of Darkness. People with high levels of self-control often choose literature from the Facts factor, ie business literature, biographies, etc. Also, such people are the least likely to read genres from the Adventure factor. High neuroticism promotes interest in various genres, united by the factor of Darkness. The low rate of neuroticism, ie emotional stability, indicates the interest of respondents in the genres of factors Facts and Adventure. Expressiveness is negatively correlated with the factors of Popularity and Adventure, and positively - with the factor of Darkness. Tolerance of uncertainty is positively correlated with the factors of Darkness and Adventure and negatively - with Facts and Popularity. The prospect of further research will be to identify the age dynamics of readers' preferences, and the presence of coincidences (differences) between readers' and viewers 'preferences.

Key words: personality, reading, genres, tolerance to uncertainty, youth. 